\title{
Mañjuśrī as Ādibuddha: The Identity of an Eight- armed Form of Mañjuśrī Found in Early Western Himalayan Buddhist Art in the Light of Three Nāmasamgīti-Related Texts
}

\author{
Anthony Tribe
}

In this article I suggest that an eight-armed Mañjuśrī found in early Western Himalayan Art be identified not as the bodhisattva Mañjuśrī but as the Ādibuddha. ${ }^{1}$ This figure is distinctive in that it holds four swords, one in each of its four right hands, and four book volumes, one in each of its four left hands. Previously identified as a form of Dharmadhātuvāgīśvara Mañjuśrī, ${ }^{2}$ this image is found in three locations in the Western Himalayas. Two of these are in Ladakh: one at Alchi in the Sumtsek (Gsum-brtsegs, "Three-Storeyed") Temple; the other at Mangyu, where there are two images, the first in the Two-armed Maitreya Chapel, the second in the Village Stuppa. ${ }^{3}$ These three images are murals. The third location is in Spiti, where there is a clay sculpture in the Golden Temple or Serkhang (Gser-khang) at Lalung. ${ }^{4}$

1 The expression "Ādibuddha," which may be rendered in English by "Original Buddha," denotes, in the present context, a figure seen as the embodiment of the gnosis ( jñ̄ana) underlying the state of Buddhahood. It is not surprising, perhaps, that Mañjuśrī, as the bodhisattva of wisdom par excellence, would be reconfigured to function additionally as the Ādibuddha.

This article, which, as will become evident, very much represents work in progress, has its origins in research on Vilāsavajra's Nāmasaṃgitti commentary, research that was supervised some twenty-five years ago by Professor Sanderson. I undertake this foray into the field of early Western Himalayan art with some trepidation: it is not an area in which I possess expertise. I have tried not to go beyond the limits of what I feel confident in claiming; nonetheless, there are bound to be errors, both of omission and commission. I offer advance apologies!

2 The Dharmadhātuvāgiśvara-maṇḍala as described by Abhayākaragupta has an eight-armed form of Mañjuśrī, named Mañjughoṣa, as its central deity (Nișpannayogāvalī-hereafter $N Y \bar{A}-54)$.

3 "Two-armed Maitreya Chapel" is the nomenclature of Luczanits 2004; van Ham 2011 uses "Maitreya Tower I." With "Village Stūpa," however, I follow van Ham's (ibid.) terminology. Luczanits (ibid.) has "Four-image Chörten," which is somewhat misleading, as while the building contains four clay images there are also mural images.

4 Regarding the dates of these temples, that of the Alchi Sumtsek is still a matter of contro-

(C) ANTHONY TRIBE, 2020 | DOI:10.1163/9789004432802_024

This is an open access chapter distributed under the terms of the CC BY-NC 4.o license thony Tribe - 9789004432802 


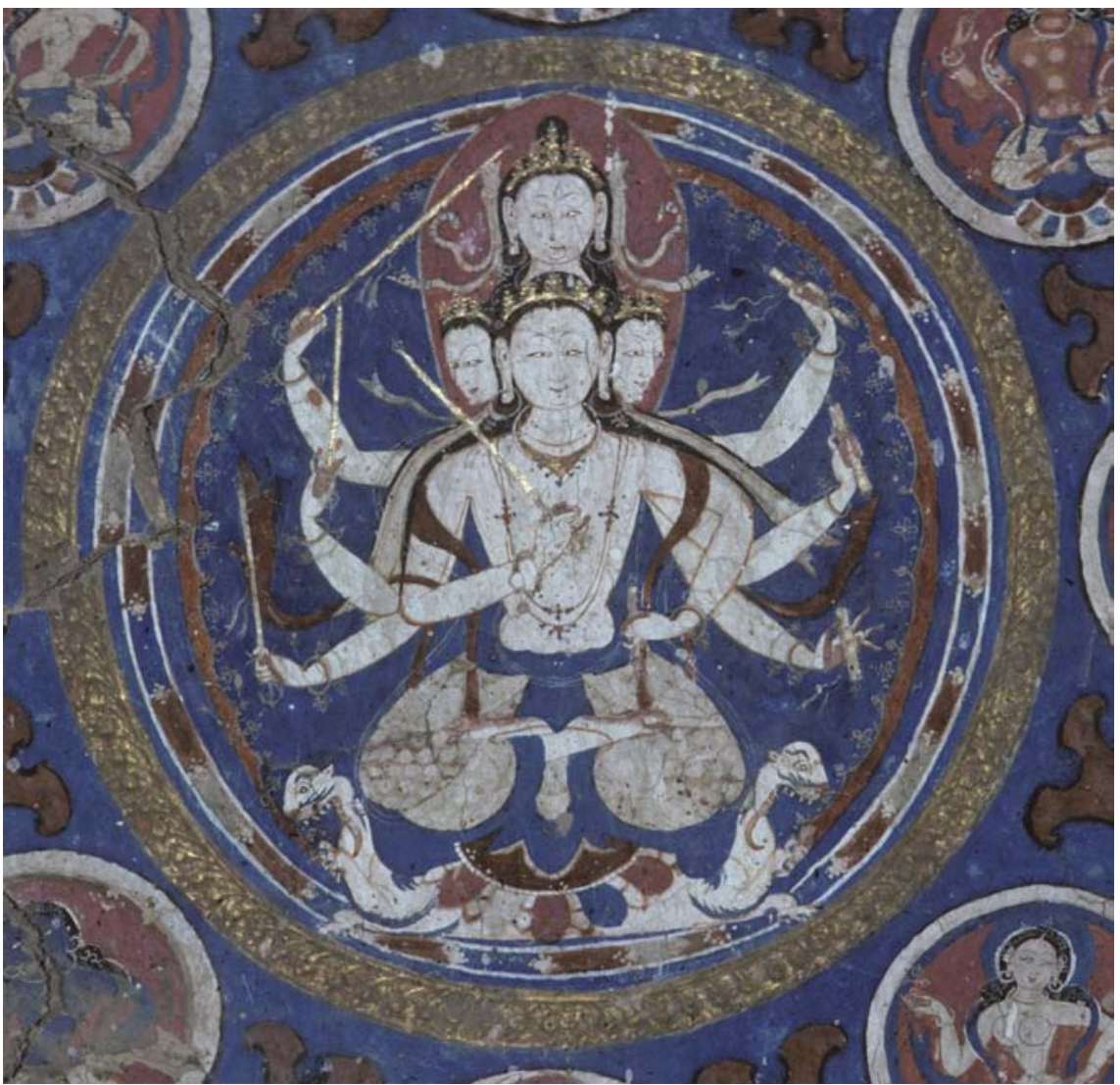

FIGURE 22.1 Eight-armed Mañjuśrī, uppermost level, Sumtsek, Alchi PHOTOGRAPH BY JAROSLAV PONCAR (JP93 26.4.05 WHAV)

The Sumtsek figure, perhaps the best known of the three, is the central deity of a fifty-three deity mandala on the top (i.e., the third) level of the temple (Figs. 22.1-2).

Being on the highest level and also on the wall opposite the temple's entrance, it occupies the place of greatest symbolic importance in the building.

versy. While the eleventh and thirteenth centuries both have their advocates (see Levy and Fidler 2014), I am inclined to agree with Linrothe's (2011) assessment of a mid-twelfth to earlythirteenth century time frame. For the Two-armed Maitreya Chapel and the Village Stūpa at Mangyu, Luczanits $(2004,170,173)$ has suggested circa 1225 as a date, and the second half of the twelfth century for the Lalung Serkhang (ibid., 106). The eight-armed Mañjuśrī under discussion is also present in the murals of the mid-fifteenth century "Great Stūpa," or Kumbum (sKu 'bum), at Gyantse, Tibet (see Ricca and Lo Bue 1993, plates 5-9; and also Tribe 2016, 899o, for a brief discussion). 


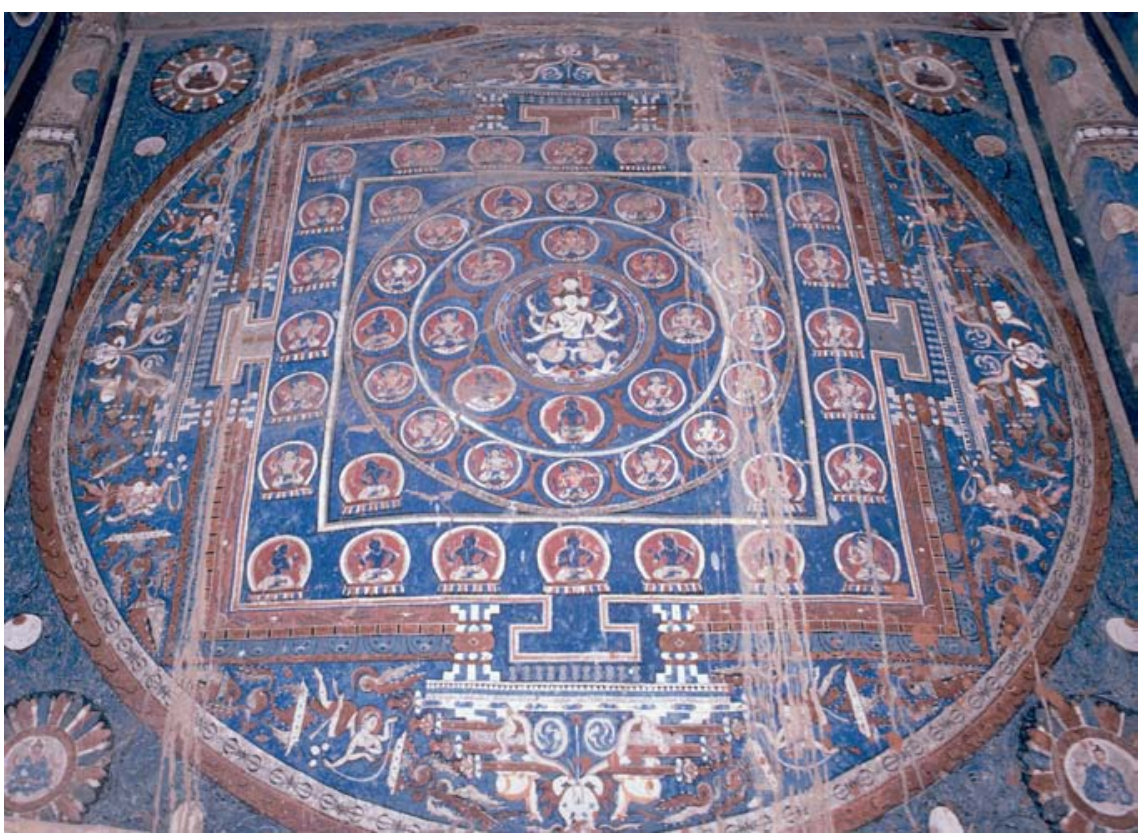

FIGURE 22.2 Maṇdala of eight-armed Mañjuśrī, uppermost level, Sumtsek, Alchi PHOTOGRAPH BY JAROSLAV PONCAR (JP83 26.4.01 WHAV)

This position has been puzzling since one might expect to find a Buddha in such a location, not a bodhisattva. Emphasizing this apparent oddity is the placing of a mandala of Vairocana on the side wall to Mañjuśri’s (proper) right. As the cosmic Buddha, Vairocana has seemingly been demoted from a more appropriate position on the back wall. ${ }^{5}$

5 For further photographs of the Sumtsek figure and the associated mandala, see Goepper and Poncar 1996, 222-223, and van Ham 2019, 344-345, 354-355. Another mural of a multi-armed Mañjuśrī holding swords in the Sumtsek should be mentioned. To the proper right of the monumental clay figure of Maitreya on the ground floor, there is, close to the floor, a seated ten-armed, five-headed, white Mañjuśrī, with each hand holding a sword. Goepper and Poncar have just two views of this figure $(1996,127,135)$, one very partial, the other small and indistinct: the location makes photography especially challenging. Van $\operatorname{Ham}(\mathbf{2 0 1 9}, \mathbf{2 3 7})$ has a better image, which shows most of the figure clearly. Four of the left hands are not visible, occluded by part of the Maitreya statue. Both van Ham (ibid.) and Goepper and Poncar $(1996,132)$ make slips in their descriptions of the figure, however, the former describing it as eight-armed, the latter as six-headed. It is clearly five-headed and the five right hands, as well as single visible left hand of the photograph, each bear a sword (van Ham states that all the hands have swords). While neither Goepper and Poncar nor van Ham attempt to identify this unusual image, van Ham (ibid.) nicely demonstrates the stylistic affinity between it and the seated figure at Mangyu by placing photographs of the two figures on the same page. 


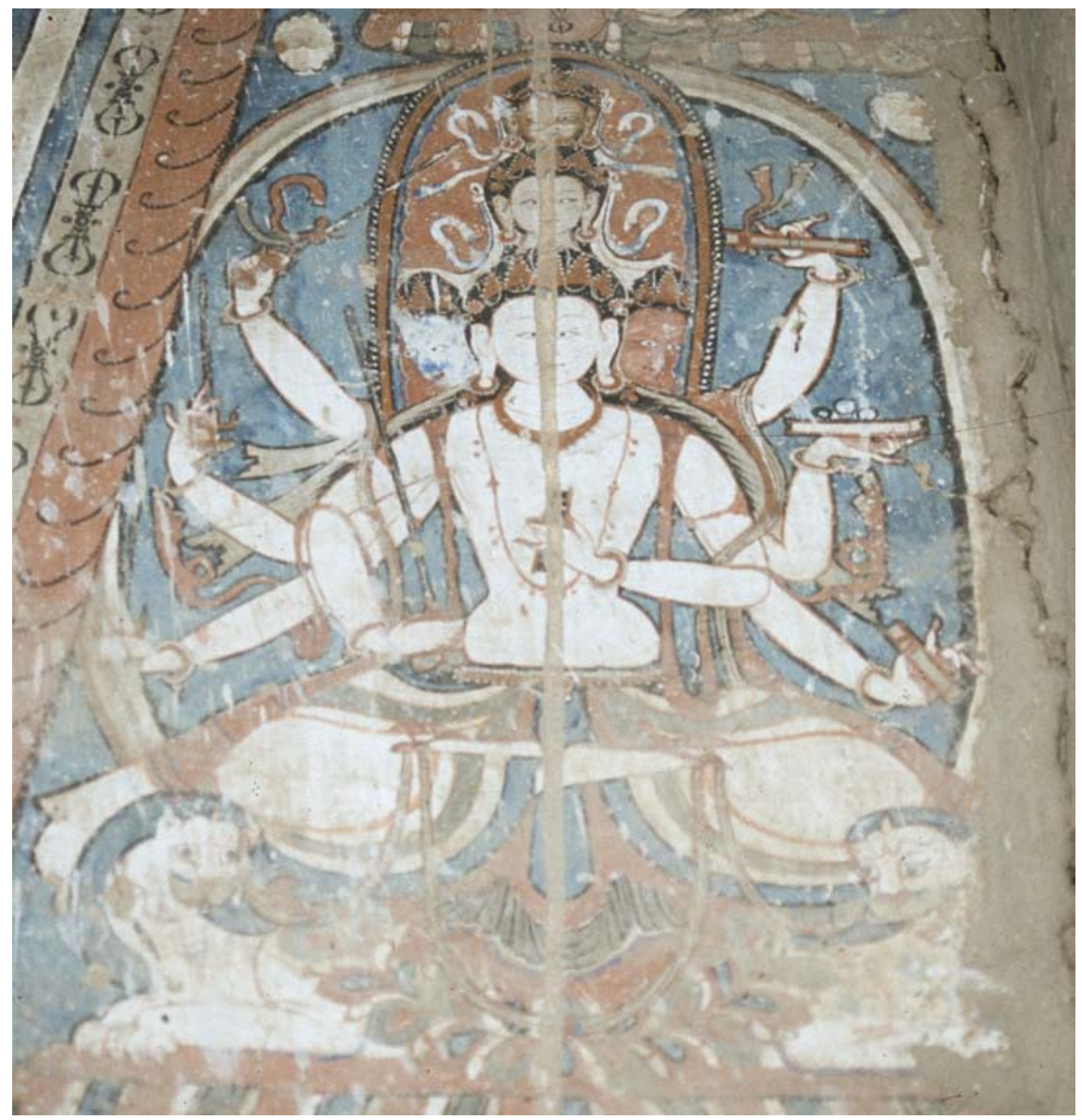

FIGURE 22.3 Eight-armed Mañjuśrī, Two-armed Maitreya Chapel, Mangyu

PHOTOGRAPH BY CHRISTIANE PAPA-KALANTARI (CPO2 44,39 WHAV)

At nearby Mangyu, the figure (Fig. 22.3) in the Two-armed Maitreya Chapel is found on the (proper) left panel of two narrow panels framing the halo of the large standing clay figure of Maitreya. It is one of a number of single figures stacked vertically, and is not surrounded by a mandala.

The second Mangyu figure (Fig. 22.4), in the Village Stūpa, is standing rather than seated, and is stylistically related to the seated figure. This form, which I have not seen elsewhere, appears to be a variant of the seated figures that were the initial and primary focus of this article. ${ }^{6}$

6 This figure is, perhaps, particular to the context of the three other murals of standing fig- 


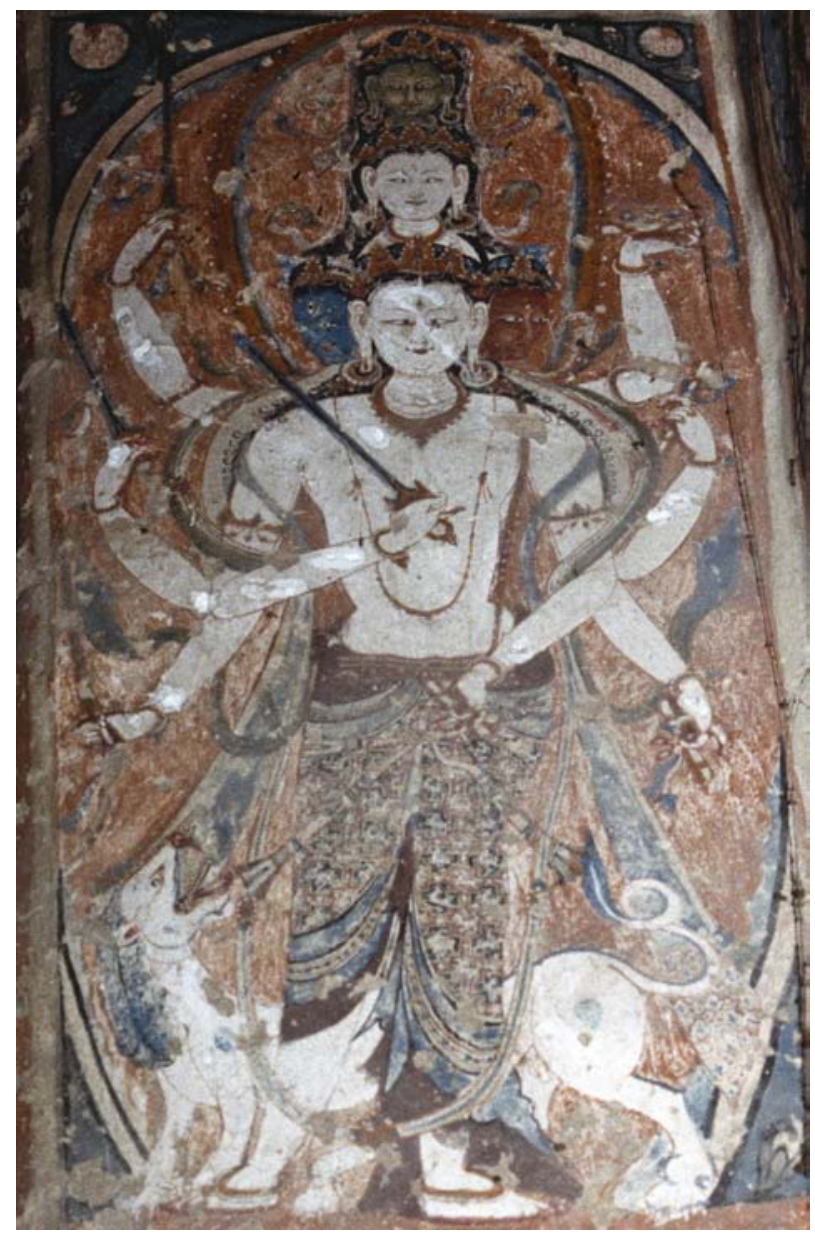

FIGURE 22.4 Standing eight-armed Mañjuśrī, Village Stūpa,

Mangyu

PHOTOGRAPH BY CHRISTIANE PAPA-KALANTARI (CPO2 41,14 WHAV)

The figure in the Lalung Serkhang (Fig. 22.5) is a clay sculpture. It no longer holds any attributes. However, like those at Mangyu and Alchi, it does not display the dharmacakra-mudrā, the standard mudrā in early Western Himalayan art for the principal hands of figures of Dharmadhātuvāgīśvara Mañjuśrīi. Each

ures—of Prajñāpāramitā, Avalokiteśvara and Tārā—in the Village Stūpa. Van Ham (2011, 45, 144) identifies both Mangyu images as Arapacana Mañjuśrī variations. For photographs of the standing Mañjuśrī see van Ham ibid., 148-149.

7 For example, in the assembly halls ('Du-khang) in Alchi and Sumda, the Two-armed Maitreya 


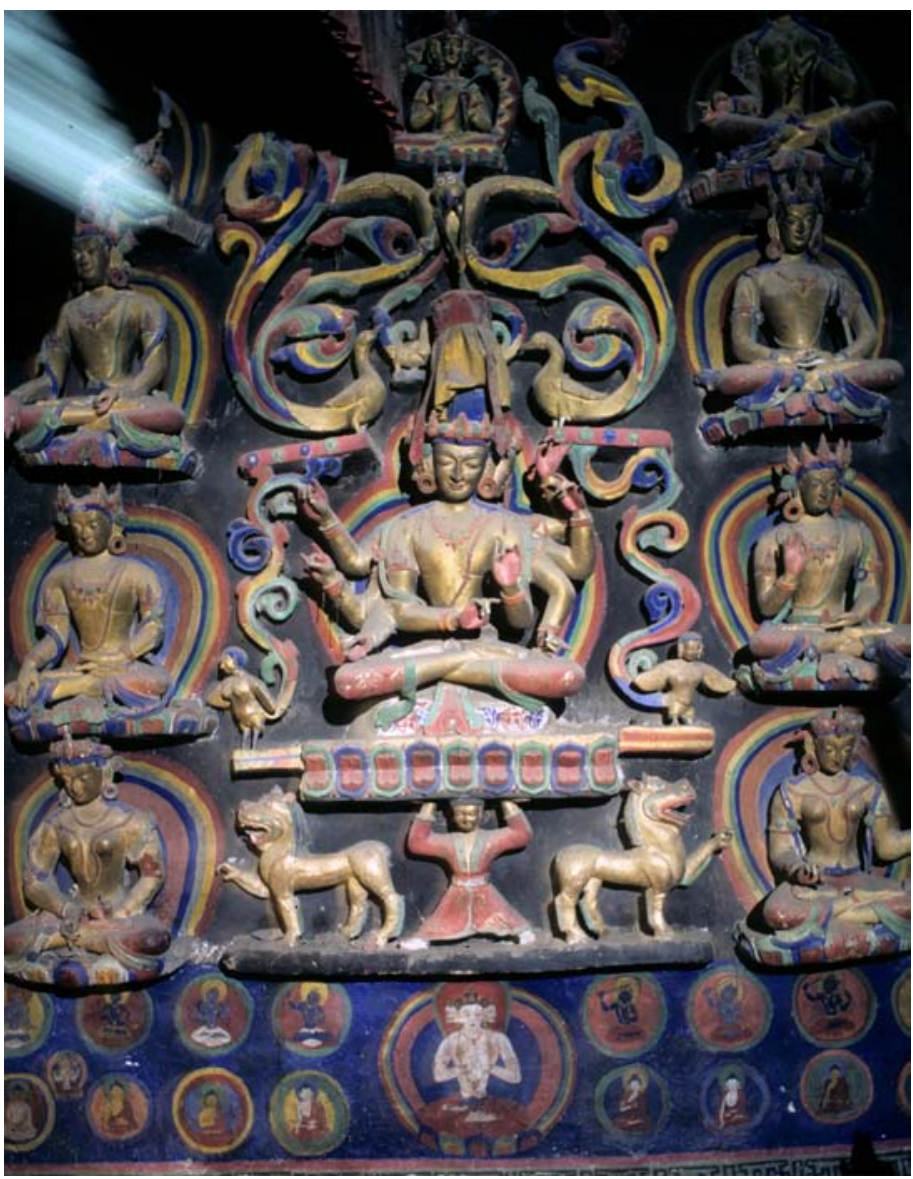

FIGURE 22.5 Maṇḍala of eight-armed Mañjuśrī, Serkhang, Lalung PHOTOGRAPH BY JAROSLAV PONCAR (JP92 500,15 WHAV)

of the eight hands of the Serkhang figure displays the same mudrä-the middle and ring fingers curled down, the middle finger touching the thumb, and the index and little fingers extended. Christian Luczanits (2004, 98-101) has convincingly argued that the Serkhang and Sumtsek figures are the same. ${ }^{8}$

Chapel in Mangyu, the Translator's Temple at Nako, and the main temple's assembly hall at Tabo. This iconography reflects the Dharmadhātuvāgīśvara-maṇdala as described by Abhayākaragupta $(N Y \bar{A} 54)$.

8 Luczanits $(2004,99)$ observes that the position of the principal right arm does not conform to his interpretation, but that there is evidence of repair work at the elbow that likely altered the arm's position. Assuming Luczanits is referring here to the figure's proper right arm, I take 
Giving further support to the identification he notes that the Serkhang Mañjuśri is flanked on each side by two columns of four further clay sculptures that form a surrounding mandala of sixteen figures. The inner two columns are comprised of four goddesses ${ }^{9}$ and the four directional tathägatas. ${ }^{10}$ These eight deities also form the first circle surrounding Mañjuśri in the Sumtsek mandala.

In what follows I will first examine the identity of the central eight-armed figure of Mañjuśrī, after which I will turn to the question of the nature of the mandalas surrounding the figures at Alchi and Lalung, as well as their lack around the Mangyu figures. The eight-armed figure, as has been noted, has previously been identified as Dharmadhātuvāgīśvara Mañjuśrīi. ${ }^{11}$ This is primarily in connection with the Sumtsek mural, and seems to be largely on the basis of the two figures having the same number of arms, and, in the case of the Sumtsek Mañjuśrī, also having the same number of heads and each being white in colour. Thus Snellgrove and Skorupski $(1977,64)$ suggested the Sumtsek Mañjuśrī corresponds to the central figure of the Dharmadhātuvāgīśvara Mañjuśrĩ of maṇdala no. 2 in the Alchi Assembly Hall ('Du-khang). ${ }^{12}$ The two

him to be suggesting that the arm/hand is in an inappropriate position to hold a sword. While he identifies the Serkhang and Sumtsek figures as the same, Luczanits identifies them as an alternative form of Dharmadhātuvāgīśvara Mañjuśrī.

9 Luczanits (2004, 100) suggests that these are Locanā, Māmakī, Pāṇ̣aravāsinī, and Tārā. However, if it is right, as I will argue, that these eight-armed Mañjuśrī figures are primarily associated with variants of the Vajradhātu-manḍala of the main yogatantra, the Tattvasamgraha, I think the four female figures are more likely to be the Vajradhātumaṇalala's four Perfections ( $p \bar{a}$ ramitā), known also as seals $(m u d r a \overline{)}$ ) and Family-mothers (kulamātr). Locanā et al. are not witnessed as a group of four until later, in texts of the yogottara/mahāyoga Guhyasamāja cycle, and likely first appearing in chapter one of the Guhyasamājatantra. Tanaka Kimiaki $(2018,134-135)$ suggests the two groups were originally from different traditions, with the Guhyasamajjatantra group evolving from a triad of kulamātṛs—Locanā, Māmakī and Pāṇdarā—in the Susiddhikaratantra, and, as a result, bypassing the Tattvasamgraha.

10 I.e., Akṣobhya (E), Ratnasaṃbhava (S), Amitābha (W), and Amoghasiddhi (N).

11 Snellgrove and Skorupski $(1977,64)$, Goepper and Poncar $(1996,223)$, Luczanits (2004, 98 99). Snellgrove and Skorupski's identification has, in lieu of alternatives, generally been accepted by subsequent writers. More recently however, given the obvious iconographical discrepancies between the Sumtsek Mañjuśrī (plus maṇdala) and the Dharmadhātuvāgīśvara-mandala, the identifications have been made with increasing degrees of caution (see, for example, Goepper and Poncar ibid., notes 151 and 153). Linrothe (1996, 272) does not follow the Dharmadhātuvāgiśvara identification, and although he does not offer a concrete alternative, he usefully explores reasons why Mañjuśrì was of significance not only in the Sumtsek and but in the Alchi complex as a whole.

12 For a photograph of this figure and first circle of the surrounding mandala see Pal and Fournier 1988, plate D 14; also van Ham 2019, 114-121, for the whole mandala and details. 
principal hands of the latter figure are in dharmacakra-mudrā. Of the remaining six, the three on the (proper) right hold in turn a sword, an arrow, and a vajra, while those on the left grasp a book, a bow, and a bell. This is standard iconography for Dharmadhātuvāgīśvara Mañjuśrī. ${ }^{13}$ Yet, as far as I am aware, a description of him holding four swords and four book volumes is textually unattested.

However, an eight-armed Mañjuśrī holding four swords and four books is described by Mañjuśrīmitra, Agrabodhi, and Vilāsavajra, all in works associated with the Nämasamgitit (hereafter NS), "The Chanting of the Names."14 The three works are Mañjuśrimitra's Ākāśavimala (D 2543, a Ns mandalavidhi), Agrabodhi's *Sādhanaupayika ${ }^{15}$ (Sgrub pai thabs, D 2579, a Ns sādhana), and Vilāsavajra's Nāmamantrārthāvalokinī (NMAA) (D 2533, a NS commentary). They were most likely composed between the mid-eighth and early-ninth centuries, and were each translated into Tibetan in the early part of the eleventh century. ${ }^{16}$ Only Vilāsavajra's text is known to survive in Sanskrit. All three authors agree in identifying this eight-armed Mañjuśrī as the Ādibuddha. Thus understood, Mañjuśri's location in the position of highest status in the Sumtsek makes sense. As the Ādibuddha, Mañjuśrī becomes the source of all Buddhas, including Vairocana to his right, as well as Prajñāpāramitā, who is at the centre

The mandala numbering is that of Snellgrove and Skorupski $(1977,38)$. It should be noted that it is mistakenly numbered as "mandala 1" (ibid., 64), which in their own numbering is a mandala with Vairocana as its central figure. Snellgrove and Skorupski state that the Sumtsek Mañjuśrī is "not [in the location he is] simply in his own right however, but in terms of the Sarvavid (Vairocana) tradition, which controls all the Alchi iconography" (ibid.). They may here be tacitly acknowledging that the maṇdala surrounding Mañjuśrī bears little resemblence to the Dharmadhātuvāgīśvara-maṇ̣ala in the 'Du-khang, and presumably suggesting that Mañjuśrī as Dharmadhātuvāgîśvara has been appropriated into a Sarvavid context.

13 This matches the description given by Abhayākaragupta (NYĀ 54, l. 6-7).

14 Also known as the Mañjuśriñamasamgìti, the $N s$ was translated into Tibetan by Rinchen Zangpo (Rinchen bzang po, 958-1055 CE), although it is likely that his was not the first translation. Rinchen Zangpo also translated the $N S$ commentaries of Mañjuśrīmitra and Mañjuśrikīrti (respectively D 2532 and D 2534), the latter being the source of the Dharmadhātuvāgîśvara-maṇạala. For an English translation and edition of the Sanskrit text of the NS see Davidson 1981. For a recent overview of the text and its contents see Tribe 2015. Very much on the right track, Linrothe $(1996,272)$ identified the $N S$ as a crucial text in trying to understand the reason for the location of the eight-armed Mañjuśrī at the top of the Alchi Sumtsek.

15 For comment on *Sädhanaupayika as a Sanskrit reconstruction of Sgrub pa'i thabs, see "Note for readers of Tibetan: What is a no pyi ka?" in van Schaik 2009.

16 On Mañjuśrīmitra and Vilāsavajra see Davidson 1981, 5-8. For a more extended discussion of Vilāsavajra's dates and life, see Tribe 2016, 21-33. 
of a mandala to his (proper) left. Mañjuśrī should no longer, at least in this form, be seen as a bodhisattva. ${ }^{17}$

The depictions of Mañjuśrī as Ādibuddha by Vilāsavajra, Mañjuśrīmitra, and Agrabodhi will be examined next. I will also comment on the relationship between the textual descriptions and the artistic depictions at Alchi, Mangyu and Lalung.

Of the three authors, Vilāsavajra's description of the Ādibuddha is the most extensive. The NMAA interprets the Nämasamgit i i within the context of a tantric sādhana ${ }^{18}$ one based on an expanded version of the Tattvasamgraha's yogatantra Vajradhātu-mandala. ${ }^{19}$ The mandala's principal deity is a four-faced Mahāvairocana, and it is in his heart that Vilāsavajra locates the Âdibuddha, depicted with eight arms holding four swords and four book volumes. The Âdibuddha is not the terminus of the interiorization process in Vilāsavajra's sādhana, however. At the Ādibuddha's heart a prajñācakra ("wisdom wheel") is visualised, on which mantras assosiated with the Nämasamgiti At the centre of the prajñācakra a final form is generated, that of Mañjuśrijñānasattva ("the gnosis-being Mañjuśrī"), who is seen as the embodiment of non-dual gnosis (advayajñāna). Mañjuśrījñānasattva is visualised as six-faced, and holding a blue lotus in each of his two hands. Each lotus is crowned with a volume of the Prajñāpāramitā. As a result, although the Ādibuddha is, in a sense, the cakreśa ("lord of the maṇdala") of Vilāsavajra's Vajradhātu-maṇạala, he is the intermediate figure of three forms, all of whom have, or share, that role.

In the fourth chapter of the NMAA, Vilāsavajra's description of the Ādibuddha directly follows that of Mahāvairocana:

\footnotetext{
17 Mañjuśrī thus transitions from being the bodhisattva of wisdom ( prajñā) to being the wisdom (now jñanna) that underlies, and is therefore conceptually prior to, Buddhahood.

18 For a critical edition and translation of the Sanskrit text of the first five chapters of the Nāmamantrārthāvalokin̄ that contains a more detailed analysis of Vilāsavajra's sādhana, see Tribe 2016. A summary of it is also available in Tribe 1997.

19 The Vajradhātu-maṇdala is more accurately called the Vajradhātu-mahāmaṇḍala. For convenience I use the shorter and more familiar form. The Tattvasamgraha is known also by the more extended title, Sarvatathägatatattvasamgraha. The shorter form is commonly found in Sanskrit sources, including the NMAA.
} 
tam evambhūtam mahāvairocanam àtmānam adhimucya caturbuddhāsanayogena taddhrdaye candramandalam tadupari dhịhkāreṇa pariniṣpannam ādibuddham bhagavantam | pañcānanam iti pañcamukham | pañcaśikham iti pañcacīrakam | tasyaiva bandhanāt pañcacīrakaśekharam | pañcavarnopetam | pürveña nülam dakșinenena pïtam paścimena raktam uttarena haritam | mürdhni paramāśvamukhavad avasthitạn mukham śvetam 〈yasya tam $\rangle \mid$ śāntam kumārābharaṇopetam saśrnigāram vicitravastraparidhānam aștabhujạ̣ śatasāhasrikām prajñāpāramitāṃ caturdhā vibhajya caturbhih karair hṛdi saṃdhār $\langle a\rangle$ yamānam | aparaiś caturbhị karaih prajñākhadgam praharañābhinayena dhārayantam caturbuddhāsanayogena vyavasthitam bhāvayet \|

TRIBE 2016, 255-256, 1l. 105-116

[The sādhaka,] on generating the conviction that he himself is Mahāvairocana as [previously] described, via the yoga of the four Buddha-thrones, should visualise a moon-disc in his heart. Above that, transformed out of the syllable dhīh, [he should visualise] the lord, the Ādibuddha. [The Ādibuddha] has five faces (pañcānana > pañcamukha). [He also] has five crests (pañcaśikha) - in other words, five hair-braids. It is through tying up those [hair-braids that he] has a crown of five hair-braids ( $p a \tilde{n}^{-}$ cacirakaśekhara). [His five faces] have five [different] colours: dark blue for the east [and forward-facing face], yellow for the south, red for the west, [and] green for the north. On the top, he has a white face, the face of [the deity] Paramāśva. He is tranquil, with the ornaments of a youth, in fine clothing, wearing about himself a many coloured garment. He has eight arms, holding at his heart with four hands the Śatasāhasrikāprajñāpäramitā ("The Perfection of Wisdom in One Hundred Thousand Lines") divided into four parts, [and] carrying, in each of the other four hands, a sword of wisdom in the gesture of striking. [All this is to be] put in place [i.e. visualised] via the yoga of the four Buddha-thrones. ${ }^{20}$

This passage is not free from textual or interpretive problems but none of them materially affects the present discussion. Although Vilāsavajra's figure corresponds to the Alchi and Mangyu Mañjuśri figures in holding the four swords and four text volumes, other aspects of the description do not completely match. Vilāsavajra's Ādibuddha has five faces, differently coloured. The Sum-

20 The translation is a slightly adapted version of the translation that accompanies the Sanskrit edition in Tribe 2016. 
tsek figure has four faces, all white. The Lalung Serkhang Mañjuśrī has three faces visible, each painted golden. ${ }^{21}$ At Mangyu, both the seated and standing Mañjuśri figures do have five faces, albeit arranged differently from the NMAA description. They likely also have the same colours, ${ }^{22}$ those of the four directions plus white for the main forward-looking face, matching their body colour. In addition, it is worth noting that in the $N M M A$ the Âdibuddha is said to hold all four volumes of the Śatasāhasrikā-prajñāpāramitā to his heart. While the seated Mangyu figure holds one book to his heart, the standing Mangyu and the Sumtsek figures hold a sword to their hearts (and no book volumes), and the Serkhang figure has one (empty) left hand raised to heart level but just to the side of his torso. ${ }^{23}$

A note of caution should perhaps be added here. It has been observed that the murals and clay sculptures of early Western Himalayan art reflect a process of Tibetan integration and adaptation of their Indian sources. ${ }^{24}$ This means that it may not always be feasible to pinpoint precise textual sources for iconography. Elements of a mandala's or image's iconography—number of heads, or colour of faces, for example-may be local adaptations, or inflections, of descriptions transmitted originally via Indian teachers and their Sanskrit texts. Bearing this proviso in mind, I hope to show that it does seem possible to rule some (broad) iconographic identifications in, and others out.

21 Luczanits $(2004,99)$ suggests a fourth head may be hidden by the (cloth-draped) umbrella above the eight-armed figure's three heads. It should be noted that the clay sculptures of early Western Himalayan art have generally been repainted, and not necessarily in their original colours. The Lalung Serkhang was completely repainted in the early zoth century Luczanits (ibid., 93-94).

22 For discussion of the facial colours of the Mangyu figures see the section on below on Mañjuśrimitra's Ākāśavimala. While this description of the Ādibuddha does not specify whether the figure is seated or standing, I think it fairly certain that the former is presupposed. Prior to the visualisations of Mahāvairocana and the Ādibuddha, the NMAA describes how the mandala, as a residence, should be visualised. The description concludes with an account of the thrones (äsana) of the deities, with a lion throne in the centre.

23 The positions of the principal hands of the seated Mangyu and Sumtsek and standing Mangyu figures are exactly reversed: left hand to heart with book, right hand to hip with sword (seated Mangyu), and left hand to hip with book, right hand to heart with sword (Sumtsek and standing Mangyu). The seated figure at Mangyu with a book held to his heart is thus closer to Vilāsavajra's description, as well as in alignment with Mañjuśrīs primary association with wisdom. In this respect the Lalung figure appears (assuming an unchanged principal left arm position) to be more affiliated with the seated Mangyu iconography.

See Luczanits $(2004,72)$ for some comments on this in relation to Tabo. 
In the above description of the Âdibuddha by Vilāsavajra, the words in bold typeface reference NS 93 (pañcānanah pañcaśikhạ̣ pañcacīrakaśekharah). When Vilāsavajra specifically comments on $N S 93$ later in the NMAA, unfortunately he does not add anything, but simply refers the reader back to the present description:

pañcānanaḥ pañcaśikhaḥ pañcacīrakaśekhara iti \|| ayam aparārdhaś cādibuddhasya gurūpadeśenādiyoge draștaryah | tatraiva vyākhyātatvāc ca punar iha nocyate $\|$

iti] AD; ti B · ayam ] AD; aryam B • aparārdhaś] corr.; aparārddhaś B; ana(șthu?)varddhaś A; anastavarddhaś $\mathrm{D} \cdot$ ihaiva māyājālābhisambodhikramoktasya mahāvairocanahṛdgatasya $\mathrm{A}$ (as a marginal addition with an insertion mark after cādibuddha) · yoge] AD; ge B

NMAA chapter 8, on NS 93cd; mss: A.69v4, B.48v3, D.11or2

With five faces. With five crests [of hair]. With a crown of five hairbraids. And this second half [of the verse] should be understood with reference to the Âdibuddha, via the teacher's instruction on the beginning yoga (ādiyoga) [phase of the sädhana]. And as it is explained there, it is not restated here.

Ms. A's marginal addition (whether scribal or a correction) somewhat superflously adds that the Ādibuddha is "in the heart of Mahāvairocana [as] stated in the "Method of Awakening according to the Mãyājāla" [i.e., in NMAA ch. 4, where the Âdibuddha is described]." Although the presence of swords and book volumes makes it hard not to see Vilāsavajra's Ādibuddha as a form of Mañjuśrī, he does not here explicitly say that he is. This is remedied later in his comment on the word ädibuddha (NS 10oab: anādinidhano buddha ädibuddho niranvayah):

ädibuddha iti || ādāv eva buddha ādibuddhah | sa ca pañcajñānātmakah ...25 evam pañcajñānātmakah pañcavarnāatmakaś cāsau bhagavān | sar-

25 This ellipsis contains a summary of the five jũānāni (gnoses) in terms of various masteries. Thus the ādarśajñānam (mirror-like gnosis) is associated with the five balāni (powers); samatājñānam (gnosis of equality), with the four vaiśäradyāni (confidences); pratyavekșaṇājñānam (discriminating gnosis), with the four pratisampvidạ (special knowledges); krtyānușthānajñānam (praxis gnosis), with friendliness (maitrī) and compassion (karuña); and suviśuddhadharmadhātujñānam (gnosis of the completely pure dharmasphere), with overlordship of everything (sarvādhipatya). These associations are referenced to the Māyajālatantra in ms. A (alone). 
vadharmasamatāmukhenaikālambanatvena draștavyaḥ sa ca mañjuśrīr ata evāsau niranvaya iti $\|$

varṇātmakaś] A; varṇārtmakaś B; varṇāś D · ālambanatvena] A; ālambanatve D; ārthatvena B · niranvaya] BD; niratvaya A.

NMAA chapter 8, on NS 10oab; mss: A.75r1, B.53r1, D.12ovı)

Ādi-buddha: [the word] a dibuddha means [he who is] "awakened from the very beginning," and that one has the five gnoses (jñānanni) as his nature ... So that one, who has the five gnoses as his nature and [also] the five colours as his nature, is the lord (bhagavann). And he should be understood to be Mañjuśrī, since as the equality of all dharmas he is the unique ground [of all phenonena]. For that very reason he is [described as] free from [causal] connection (niranvaya).

To summarize, Vilāsavajra has clearly identified an eight-armed figure holding four swords and four books as the Ādibuddha, and has stated that the Ādibuddha is also Mañjuśrī. At the same time, there are some discrepences between Vilāsavajra's description and the images at Alchi, Mangyu and Lalung. There is also some variance of appearance between each of the four (three mural and one clay) temple figures.

The likelihood of Vilāsavajra's text—or Agrabodhi's, as we shall see—being of influence in the iconography of these figures is given support by the existence of a small clay figure directly above the eight-armed Mañjuśrī in the Lalung Serkhang (Fig. 22.6). The figure is two-armed, each hand holding a lotus stem. The two stems each rise to a flower base, one on each side of the figure a little above its shoulders. ${ }^{26}$

If it is correct to identify the central eight-armed figure as the Âdibuddha, then I think the two-armed figure may be Mañjuśrījñānasattva, who in

26 This distinctive figure was noted by Tucci $(1988,118)$, who, having identified the Ādibuddha figure as "Vairocana or one of his emanations" (ibid., 117), on the basis that the central figure was surrounded by the four directional tathägatas, briefly observed that the figure above was Sarvavid. More recently this image has been discussed at greater length by Luczanits (2004, 99-100, 208-209), who notes the figure's unusual iconography and suggests a possible link with the sun-god Sūrya, who holds two lotuses similarly. This in turn, he suggests, supports the hypothesis that the figure is a form of Vairocana given the word vairocana means "resplendent, exceeedingly bright." In fact, the link between Vairocana and the sun is stronger than Luczanits perhaps realised: the literal Sanskrit meaning of vairocana is "coming from or belonging to the sun (virocana)." Also, Edgerton (1953 II, 512) suggests that in Buddhist contexts virocana, "the sun," and its derivative vairocana, can be synonymous. 


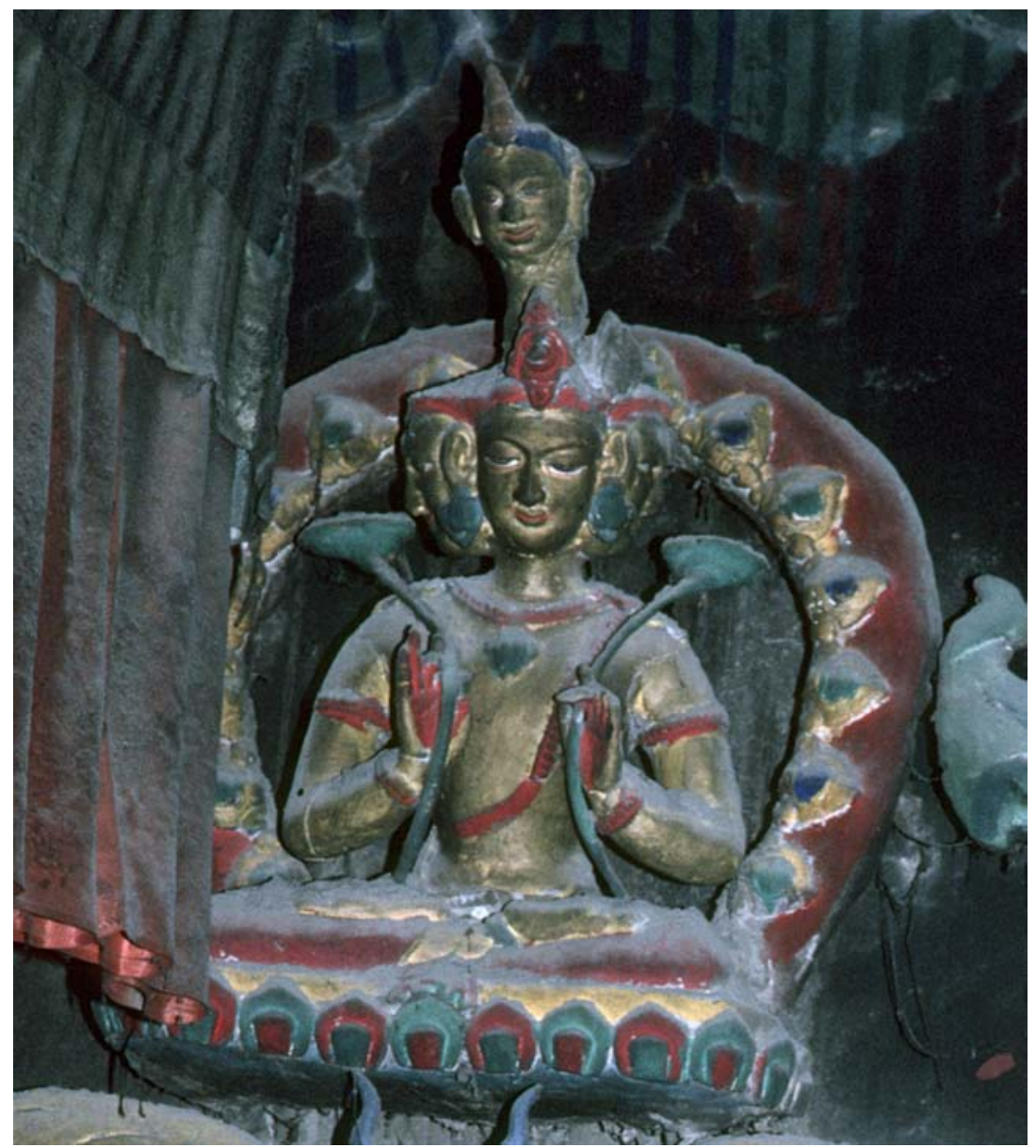

FIGURE 22.6 Two-armed Mañjuśrī (as Jñānasattva), Serkhang, Lalung PHOTOGRAPH BY CHRISTIAN LUCZANITS (CL91 52,6 WHAV)

the NMAA is visualised in the heart of the Ādibuddha. Vilāsavajra describes Mañjuśrī-jñānasattva as follows:

tasya cakrasya madhyavartinam akārajam bhagavantạ̣ șaṇmukham jñānasattvam śaracchaśāñkaprabham indranīlāgrasaccīram bālārkamaṇdalacchāyaprabhāmaṇdalam sarvatathāgatamayābharanam samādhisamāpannam vicitrapadmāsanopaviștam ubhayakarāsaktanīlotpalordhvasthitaprajñāpāramitāpustakadvayam śāntarasopetam ātmānam vicintya

TRIBE 2O16, 26o, 1l. 172-176 
[Next] he should visualise himself as the fortunate one, the gnosis-being [Mañjuśrī], born from the syllable $a$ situated in the middle of that [wisdom-]wheel [situated in the heart of the Âdibuddha]. He has six faces, is radiant like the autumn moon, with the best of sapphires in his beautiful hair, with a halo that has the brilliance of the orb of the newly risen sun, with all the tathägatas as [head-]ornaments, immersed in meditative concentration, seated on a variagated lotus throne, in tranquil mood, with a pair of books of the Prajñāpāramitā above blue lotuses held in his two hands.

The figure in the Serkhang is missing the volumes of the Prajñaparamitāa as is the eight-armed Mañjuśrī below him. ${ }^{27}$ There is also a discrepancy in the count of heads. Vilāsavajra has six for Mañjuśrī-jñānasattva (one more than the Ādibuddha, who in turn has one more than Mahāvairocana, the outermost figure of the central nested triad). Although the Serkhang figure has just four heads, the fourth is about a head's distance above the tops of the first three heads. The result is that the figure looks distinctly odd, with one head floating above the other three. It does not seem impossible (and it would certainly improve the aesthetics) that there were originally two further heads in between the bottom three and single top head, giving a pyramidal structure of three + two + one heads, i.e. six altogether, matching Vilāsavajra's description.

There is also a small figure in direct vertical alignment with the two-armed and eight-armed sculptures, immediately beneath the (let us assume) Ādibuddha's lion throne. It is a mural of a white four-faced Mahāvairocana, two-armed and simply attired, with his hands in dharmacakra-mudrā (see Fig. 22.5). ${ }^{28}$ His location may be coincidental, but if not, he completes Vilāsavajra's triad of Mahāvairocana, the Ādibuddha, and Mañjuśrī-jñānasattva. The location of Mahāvairocana beneath the other two figures is hard to explain unless he is somehow understood to be subordinate to them, which is precisely what Vilāsavajra is saying. ${ }^{29}$

Vilāsavajra describes Mahāvairocana as follows:

27 That the Ādibuddha lost the four volumes of the Prajñāpa ramitā apparantly without damaging the hand $m u d r a \bar{s}$ suggests that they were easily removable. The same detachability may have applied to the two-armed figure.

28 Luczanits (2004, 93-94) notes that while the Serkhang murals were repainted crudely during the early twentieth century, it appears that the repainting followed what was present before.

29 Namely that Mahāvairocana (= all samādhis) has the Ādibuddha (= the pañcajñāna) as his nature, who in turn has Mañjuśrī-jñānasattva (= advayajñāna $)$ as his nature. It is possible that the Mahāvairocana mural is not part of the clay sculpture maṇdala at all, and 
tataś ca pradhānāsana āhkāreṇa parinișpannam mahāvairocanam | yato yad eva cittam prakrtyā grāhakādyākāravirahād dharmadhātusvabhāvam tad eva caturmukham śünyatādicaturvimokșamukhānām dharmadhātor ālambanatvena sarvasamādhiprasūtihetutvāt | śuklavarnạn dharmadhātusvabhāvatvāt |jațāmakuțopetam nirābharanam ca śāntacittatvāt |bodhyagrīmudrāyuktam prajñopāyātmakatvāt

TRIBE 2016, 255, ll. 100-105

And then [the sādhaka should visualise] Mahāvairocana on the principal seat, generated by means of the syllable $\bar{a} h$. [Why has he four faces?] Since consciousness - which is of the nature of the Dharma-Sphere since, by its nature, it lacks such forms as the grasped [i.e., the subject-object duality] - is four-faced. [This is] because the four liberation faces [/doors] (vimokșamukha) —emptiness and the rest—are the cause of the origination of all meditative concentrations (samādhi), [and this in turn is] because their ground is the Dharma-Sphere. He is white in colour because he has the Dharma-Sphere as his nature. He has braids of hair [stacked up on his head] as a crown and is unadorned because he is one whose mind is tranquil. Since he has both wisdom and means as his nature he makes the bodhyagri ("highest awakening") hand gesture. ${ }^{30}$

In contrast with Vilāsavajra's description, the Serkhang Mahāvairocana is not "unadorned". He has armlets, bracelets and two necklaces. Yet he is is still fairly simply adorned, with no clothes on his upper body and with his hair stacked behind a minimal crown. ${ }^{31} \mathrm{He}$ is two-armed but with his hands in

that the significance of his location should be understood just in relation to the two rows of deities that flank him to each side. However, this same vertical alignment of the three figures of Vilāsavajra's NMAA is also found in a Tibetan thangka of unknown provenance, a photograph of which was kindly sent to me by Tanaka Kimiaki. In the thangka the central figure is Mañjuśrī-jñānasattva, however, with the eight-armed Ādibuddha above him, and a small four-headed Mahāvairocana beneath him; and as in the Serkhang, the three central figures are surrounded by the four directional tathāgatas and four kulamātrs.

30 bodhyagrī-mudrā. In this mudrā the extended and raised left forefinger is grasped and encircled by the fingers of the right hand, the hands being held at the heart. The Tattvasamgraha $(89,4-5)$ describes it as follows: "The raised left vajra-finger should be grasped with the right [hand]. This mudrā, which bestows the awakening of the Buddhas, is called bodhyagrı̄" (vāmavajrāngulir grāhyā [em.; grāhya Ed.] dakșineña samutthitā | bodhyagrī [em.; bodhāgrī Ed.] nāma mudreyam buddhabodhipradāyikā). For discussion of variants of this mudrā and confusion surrounding its name, see Tribe 2016, 9o-92.

31 A good example of a mural of an unadorned (i.e., with no jewelry and simple clothing) Mahāvairocana with a crown of stacked hair (jațāmakuța) is present in the Gyantse Kum- 
dharmacakra-mudrā rather than bodhyagri-mudra ${ }^{32}$ Nevertheless, although Vilāsavajra's description does not exactly match the Serkhang figure, its broad correspondence, and especially its location, is striking.

Before discussing Mañjuśrīmitra's and Agrabodhi's texts, it is worth noting that Vilāsavarja makes a clear distinction between Mañjuśrī as jñānasattva and as bodhisattva:

jñānasattva iti sarvatathāgatahrdayavihāritvāt | mañjuśrišs cāsau jñānasattvaś ceti mañjuśrï̄ñānasattvaḥ | nāyam daśabhümišvaro bodhisattvaḥ kiṃ tarhy advayajñānam prajñāpāramitā saiva mañjuśrïjñānasattvaḥ

TRIBE 2016, 236, ll. 215-218

He is [described in $N S 10$ as] the jñänasattva since he dwells in the heart of all the tathägatas. The jñānasattva Mañjuśri is not the bodhisattva that is the master of the ten [bodhisattva] stages. Rather, he is non-dual gnosis (advayajñāna), the perfection of wisdom ( prajñāpāramitā) itself.. ${ }^{33}$

If Mañjuśrī-jñānasattva should not be identified with the bodhisattva Mañjuśrī, then by extension, this should equally apply to Mañjuśrī as the Ādibuddha. Understanding this helps makes sense of the iconographic programme of the Sumtsek (and by extension of the three figures in vertical alignment in the Lalung Serkhang). Tucci (1988, 117-118) proposed that the two clay figures in the Lalung Serkhang were manifestations or forms of Vairocana or Mahāvairocana. In the present reading the inverse is true: Mañjuśri the Âdibuddha manifests Mahāvairocana. And by implication, he also manifests Mañjuśrĩ the bodhisattva along with all the tathägatas and other bodhisattvas. Thus at Lalung it is the jñānasattva Mañjuśrī, as the topmost figure, that can be read as manifesting, in turn, the Ādibuddha and Mahāvairocana.

bum (see Ricca and Lo Bue 1993, plate 5). If jațāmakuța is analysed as a dvandva rather than a karmadhäraya compound it can be translated as "having a crown and stacked hair." For a Mahāvairocana depicted in this way, also in the Kumbum, with a large crown in front of stacked hair see Ricca and Lo Bue ibid., plate 4.

32 The Alchi 'Du-khang has a mural of four-faced, two-armed Mahāvairocana with his hands in bodhyagri-mudrā (see Pal and Fournier 1988, plate D 5; van Ham 2019, 94-95). Like the Sumtsek eight-armed Ādibuddha, this figure has its fourth head stacked centrally above the others. In contrast, the Serkhang Mahāvairocana has all four heads on the same level, with two to the proper right of the front face, and one to the left.

The karmadhāraya analysis of mañjuśrïjñannasattva is omitted from the translation. 
Mañjuśrīmitra, who may have been an older contemporary of Vilāsavajra, wrote extensively on the Nämasamgitti. ${ }^{34}$ In the $\bar{A} k a \bar{s}$ avimala, he describes both the Ādibuddha and Mañjuśrī-jñānasattva, albeit more briefly than Vilāsavjara. First, the Ādibuddha:

dang po'i sangs rgyas zhal lnga pa $\mid$ phyag brgyad pa $\mid$ gyas bzhin shes rab kyi ral gri $\mid$ g.yon bzhin shes rab kyi pha rol tu phyin pait po ti yod pa $\mid$ zhal bzhi phyogs dang mthun pa | dbus dmar ser ro $\mid$

D $2543,4 \mathrm{r}^{-4}$

The Ādibuddha has five faces and eight arms. In the right [arms] are sword[s] of wisdom; in the left volume[s] of the Prajñāpāramitā. The four faces correspond [in colour] to the directions. The central face is orange.

Mañjuśrimmitra and Vilāsavajra agree on the key iconographical elements. There is one significant difference in that Vilāsavajra's fifth face is white, Mañjuśrīmitra's is orange. As noted earlier, the seated figure at Mangyu has five faces (unlike the four-faced Sumtsek figure), and the top and fifth face appears to be orange-brown. However, it is likely to have originally been green. If it were orange it would point to Mañjuśrimmitra as a possible textual source, although he does not describe a white face, which is the colour of the principal faces for both Mangyu figures. The likely explanation of the orange-brown colour of the top face of the seated Mangyu figure is that the original colour has faded over time. It is clear from the Sumtsek mandala that while reds and blues preserve their colour fairly well over time, greens and yellows can fade; in the Sumtsek instance, they both faded to a pale reddish brown. ${ }^{35}$ The arrangement of heads in both the Mangyu figures (seated and standing) is the same: three heads at the same level (front, left and right facing), surmounted by two further heads, one above the other. The topmost face of the standing Mangyu figure is clearly green, in contrast to the orange-brown of the seated figure. The intermediate face colouring for both is similar: very pale brown for the seated figure and offwhite for the figure standing. The colours of the three horizontal lower faces are identical: white (to the front), flanked by blue (to the proper right) and red (to the left). If green is correct for the topmost face, and if it is assumed that an

34 Davidson $\left(1981,5^{-6}\right)$ dates Mañjuśrīmitra to the mid-eighth century and notes that Buston records a tradition that he may have been Vilāsavajra's teacher.

35 See below, note 40. In the Mangyu figures yellow appears to fade almost to white. 
original yellow of the intermediate faces has faded, then both figures have the same head arrangement and colouring. These colours are those described by Vilāsavajra. The head arrangement differs, however: Vilāsavajra has four heads (representing the four directional tathägatas) at the same level, each facing one of the four directions, and the fifth central (principal) white head above the four. The Mangyu arrangement could be understood as an adaptation to the constraints of two dimensional mural painting. ${ }^{36}$

Turning to Mañjuśrīmitra's description of Mañjuśrījñānasattva, it is also structurally parallel to that of Vilāsavajra and immediately follows his description of the Âdibuddha:

de'i thugs kar shes rab kyi 'khor lo rtsibs drug pa la | gsang sngags rgyal po drug gis mtshan pa | de'i kyil du 'jam dpal ye shes sems dpa'zhal drug phag gryis pa $\mid$ g.yas ral gris g.yon po ti'dzin pa

D $2543,4 \mathrm{r} 4$

In his (i.e. the Âdibuddha's) heart is a wisdom wheel (prajñ $\bar{a}-c a k r a)$, sixspoked, ornamented with the six secret mantra kings. In its centre is Mañjuśrī-jñānasattva, with six faces [and] two hands. The right [hand] carries a sword, the left a book.

Again there is a significant difference between Mañjuśrīmitra and Vilāsavajra. Vilāsavajra’s Mañjuśrī-jñānasattva does not hold a sword and a book, but has a lotus stem in each hand, each topped with a book. If it is correct to identify the two-armed figure in the Lalung Serkhang above the Ādibuddha as Mañjuśrījñānasattva, Vilāsavajra seems a more likely iconographical source than Mañjuśrīmitra.

\section{Agrabodhi's *Sādhanaupayika}

Agrabodhi (Tib. Byang chub mchog) is described as Vilāsavajra's maternal uncle in the NMAA's colophon. ${ }^{37}$ This makes him a contemporary of both Mañjuśrī-

36 In the murals of these eight-armed Mañjuśrī figures at Mangyu and in the Sumtsek the principal face and body is white in each case, indicating their alignment with Mahāvairocana, whose distinctive colour is also white, and who is so described by Vilāsavajra above: śuklavarnạm dharmadhātusvabhāvatvāt, "He is white in colour because he has the Dharma-Sphere as his nature."

37 Byang chub mchog has been standardly reconstructed as *Varabodhi. For discussion of the NMAA's colophon see Tribe 2016, 25-28 and Appendix 3. 
mitra and Vilāsavajra, and probably the latter's elder. In his Nāmasamgìti *Sādhanaupayika Agrabodhi also describes the Ādibuddha and Mañjuśrījñānasattva. Again, first the Ādibuddha:

dang po'i sangs rgyas zhal lnga pa || byis pa'i rgyan gyis rnam brgyan cing || rin chen sna tshogs na bza'can || phyag brgyad mnga' ba'i phyag mtshan ni || g.yas pa bzhi ni go rims bzhin || shes rab kyi ni ral gri bsnams || de bzhin g.yon pa'i phyag bzhi na || shes rab pha rol phyin pa yi || po ti re re bsnams pa'o ||

D 2579, 62v7-63r1

The Âdibuddha has five faces. He is adorned with the ornaments of youth, and [wears] garments [decorated] with various gems. He has eight hands. As for the attributes held by the hands: the four right hands in turn carry a sword of wisdom; similarly, the four left hands each carry a volume of the Prajñāpāramitā.

The basic iconography of five faces and eight arms (with swords, and volumes of the Prajñāpāramitā) follows Vilāsavajra and Mañjuśrīmitra. Although the description is a little more elaborate than Mañjuśrimitra's, Agrabodhi omits colours for the Ādibuddha's faces. Agrabodhi's description of Mañjuśrījñānasattva follows a half folio later:

ye shes sems dpa'zhal drug pa || ston ka'izla ba ltar gsal zhing || indra nïla'i gtsug phud can || nyima 'charka'i'od'dras bskor||zhi ba'ingang tshul dang ldan zhing || g.yas dang g.yon gyi phag gnyis kyis || utpala dmar po g.yas pa ni $\mid$ g.yon pa na ni sngon po nyid || utpala de gnyis steng nyid na $\mid$ shes rab po tis mdzes pa'o ||

D 2579, 63v.2-3

Mañjuśrī-jñānasattva has six faces. He is luminous like the autumn moon, with the choicest sapphire as a [head] crest. He is encircled as if by the light of the rising sun, and he has a peaceful disposition. With [his] two hands - right and left- [he holds] a red lotus in the right, a blue one in the left. Adorning the top of [each of] those two lotuses is a volume of Prajñā $[$ paramitā $]$.

All three authors agree, then, that Mañjuśrījñānasattva has six heads and two arms; and Agrabodhi and Vilāsavajra concur (against Mañjuśrīmitra) that he holds two lotuses topped with books. Agrabodhi and Vilāsavajra differ, 
however, in the colour of the lotuses. Agrabodhi has one red and one blue; Vilāsavajra has them both be blue. As noted, the Serkhang scultpures have been repainted in the twentieth century ${ }^{38}$ and at present the Mañjuśri-jñānasattva figure has two green lotuses. In conclusion, either Agrabodhi or Vilāsavajra or both could be a source for the Serkhang figures. All three authors also share the same core structure for their sādhanas, with the Ādibuddha in Mahāvairocana's heart, a wisdom-wheel within the Ādibuddha's heart, and Mañjuśrījñānasattva in the centre of the wisdom-wheel. And like Vilāsasvajra, both Mañjuśrimmitra and Agrabodhi describe Mahāvairocana with four heads, and with hands in bodhyagrī-mudrā..$^{39}$

\section{$4 \quad$ Broader Iconographic Contexts}

Some remarks about the mandalas surrounding the Mañjuśrī Ādibuddha figures at Alchi and Lalung, and the lack of any at Mangyu, follow. First, the Alchi Sumtsek. While I am not able to clearly identify either Mañjuśrīmitra, Vilāsavajra or Agrabodhi as providing the textual source for the mandala, one thing is clear: it is not a maṇdala of Dharmadhātuvāgīśvara Mañjuśrī. This is the case irrespective of the identity of the central deity.

The Sumtsek mandala (Fig. 22.2) contains fifty-three figures in total, all contained within a single four-gated square courtyard. Within the courtyard is another (ungated) square that contains two circles surrounding the central deity. The first of these circles contains eight figures, the second sixteen. In the first circle in the intermediate directions are the four family mothers ( kula$m \bar{a} t r$ ), identifiable by the family symbols they hold (vajra, gem, lotus, viśvavajra). In the four cardinal directions are the four directional tathägatas, indicated by their mudrä, animal/mount (vähana) and colour. ${ }^{40}$ The second circle may well contain the sixteen samādhi deities of the Vajradhātu-maṇala. Each

38 See above, note 21.

39 See Ākāśavimala D 2543, 4r2-3; *Sädhanaupayika D 2579, 62v6-7

40 While Akṣobhya (blue) and Amitābha (red) have their colours, Ratnasambhava and Amoghasiddhi are a similar pale reddish brown. Their original colours have likely faded, both here and throughout the mandala. The colour of the garment on the Âdibuddha's legs is a similar, presumably faded, colour; it is possible to discern the remains of a floral pattern on the leg coverings. The high status of this figure is perhaps further reflected in the use of gold paint, not only for the slightly embossed circle that surrounds him and for the crowns on his heads, but also for the swords and book volumes. Close inspection also reveals that both ends of each sword and book volume are adorned with a terminus of vajra prongs. 
figure is iconographically distinct, although with the exception of Vajrarāga (E), Vajraratna? (SE), Vajratejas/Vajrasūrya (SSE), Vajratīkș̣na (S), and Vajrayakșa (N) I have not been able to make clear identifications. ${ }^{41}$ In the corners between the second circle and the ungated square are four offering goddesses.

Beyond the square, in the space between it and the main gated courtyard walls are the remaining figures, twenty-four altogether. The corners are occupied by four further offering goddesses. This leaves five figures on each side. The members of each group of five have the same colour (that of their presiding tathägata) and hold the attribute definitive of their family (i.e. vajra, gem, lotus, or viśvavajra).$^{42}$ It is tempting to identify sixteen of these figures as (non iconographically individuated) bodhisattvas. This would leave the remaining four as door guardians. ${ }^{43}$

The Dharmadhātuvāgīśvara-maṇạala in the Alchi 'Du-khang that, according to Snellgrove and Skorupski $(1977,64)$, corresponds to the Sumtsek mandala also has eight figures in a circle surrounding the central deity. In this the two mandalas are structurally alike. The figures in the 'Du-khang circle, however, are the eight uṣnissa deities, iconographyically identical. Beyond this, and within the first of three gated courtyards are four eight-armed tathāgatas and four eight-armed goddesses. ${ }^{44}$ As the existence of three courtyards suggests, the Dharmadhātuvāgiśvara-maṇạala is large, with over two hundred deities. ${ }^{45}$ The Sumtsek maṇdala should, I believe, be identified instead as a Vajradhātumandala variant. If the sixteen putative bodhisattva figures are excluded, the mandala is identical to the thirty-seven deity Vajradhātu-mandala of the Tattvasamgraha. A set of sixteen bodhisattvas often supplements the deities of the Tattvasamgraha in later Vajradhātu-maṇala descriptions. These are generally the sixteen bodhisattvas of the present aeon (bhadrakalpa), as described for example in Abhayākaragupta's Nișpannayogāvalī Vajradhātu-maṇạala. ${ }^{46}$

41 Also, some of the directional locations of the identifiable figures are unusual: for example Vajratìkṣna, standardly associated with Amitābha and the west, is in the south.

42 As with their tathägatas, the colours of the southern and northern deities appear to have faded.

43 However, those that occupy the positions of door guardians are not iconographically distinct from their neighbours.

44 For photographs of Dharmadhātuvāgî́vara Mañjuśrī and the uṣṇiṣa deities, see van Ham 2019, 115, and Pal and Fournier 1988, plate D 14. For examples of the tathāgatas and goddesses see van Ham ibid. 115-116, and Pal and Fournier ibid., plates D 15-18.

45 For Abhayākaragupta's description of the Dharmadhātuvāgīśvara-maṇdala, which contains two hundred and sixteen figures, see $N Y \bar{A} 54 \mathrm{ff}$.

46 See $N Y \bar{A}$ 44ff. The same list is also present in Abhayākaragupta's Durgatipariśodhanamaṇ̦ala (NYĀ $66 \mathrm{ff}$.$) .$ 
In assessing possible textual sources for the Sumtsek and Lalung mandalas, at present I am only able to comment on the mandala elaborated by Vilāsavajra around the triple central figure(s) of Mahāvairocana, the Ādibuddha and Mañjuśrí-jñannasattva. ${ }^{47}$ It too is a fifty-three deity (if the central triad is counted as one) Vajradhātu-maṇdala variant. The deities are enumerated/emanated in the following order: four family mothers (kulamātr $),{ }^{48}$ four tathāgatas, sixteen samādhi deities, eight offering goddesses ( $p \bar{u} j \bar{a} d e v \bar{\imath})$, four gate guardians (dvārapāla), and sixteen bodhisattvas. While Vilāsavajra elaborately connects these deities with doctrinal categories and Nämasamgiti "names," he gives no iconographical descriptions. Also, while the sixteen putative bodhisattva figures of the Sumtsek mandala are not distinguished beyond their family affiliation, the NMAA set is not the same as the bhadrakalpa group. ${ }^{49}$ Thus while the Sumtsek mañ dala could be derived from Vilāsavajra's NMAA, further investigation may reveal a more immediate source.

Turning very briefly to the deities surrounding the Âdibuddha figure in the Lalung Serkhang, it was seen earlier that (again counting the central triad as one figure) they comprise a mandala of seventeen figures, two columns of four figures positioned to each side of the Ādibuddha. It was also noted that Luczanits (2004, 98-101) identified the eight figures of the two inner columns as identical with the figures in the first circle surrounding the Ādibuddha in the Sumtsek

47 Vilāsavajra enumerates the NMAA maṇdala deities in chapter five (associating each with a "name" from the $N S$ ).

48 Namely Sattvavajrī, Ratnavajrī, Dharmavajrī and Karmavajrī. Although the core thirtyseven deities of Vilāsavajra's maṇdala (i.e., discounting the sixteen bodhisattvas) are identical in name and number with those of the Tattvasamgraha, the order of emanation of the four family mothers - also described in both texts as Perfections ( pāramitā $)$-differs. In the Tattvasamgraha they appear after the sixteen samādhi deities (and before the eight offering goddesses and four door guardians). In the NMAA they comprise the initial manifestation of non-dual gnosis. Their more central position can perhaps be seen as reflecting the changing status — the increasing centrality—of the feminine within tantric Buddhism during this period.

49 Maitreya and Amoghadarśin are the first two members of the sixteen bhadrakalpa bodhisattvas (followed by Apāyañjaha, Sarvaśokatamonirghātamati, Gandhahastin, Surañgama, Gaganagañja, Jñānaketu, Amṛtaprabha, Candraprabha, Bhadrapāla, Jālinīprabha, Vajragarbha, Akșayamati, Pratibhānakūṭa, and Samantabhadra). The NMAA list is headed by Maitreya and Mañjuśrī (followed by Gandhahastin, Jñānaketu, Bhadrapāla, Sāgaramati, Akṣayamati, Pratibhānakūṭa, Mahāstāmaprāpta, Sarvāpāyañjaha, Sarvaśokatamonirghātamati, Jālinīprabha, Candraprabha, Amitaprabha, Gaganagañja, and Sarvanivaraṇaviṣkambhin). That Mañjuśrī is enumerated here underlines the notion that Vilāsavajra sees Mañjuśrī-as-jñānasattva emanating Mañjuśrī-as-bodhisattva. The NMAA set is also found in Abhayākaragupta's forty-three deity Mañjuvajra-maṇḍala (Tricatvāriṃśadātmakamañjuvajra-mạ̣dala: see $N Y \bar{A} 5^{\circ}$ ). 
at Alchi. He also identified the outer eight figures as offering goddesses. This seventeen-figure mandala could be derived from Vilāsavajra's NMAA maṇdala, as an abbreviated version. Alternatively, the two rows of mural figures painted below the Ādibuddha, which flank Mahāvairocana may be part of a larger maṇdala.${ }^{50}$ Whether the mandala, larger or smaller, is described more precisely by Agrabodhi or Vilāsavajra requires further investigation.

While the Alchi and Lalung figures each have a mandala as their immediate iconographic context - a context that makes sense of, and supports, their identification as Mañjuśri Ādibuddha-this is not the case for the two figures at Mangyu, neither of which is at the centre of a mandala. In the Two-armed Maitreya Chapel the seated Ādibuddha figure has no especial prominencebeing one among ten deities that flank the large two-armed clay statue of Maitreya, five on each side. The iconographic programme of these figures is unclear, as they do not appear to constitute a mandala. Among them are also two additional Mañjuśri figures, one of which is a six-headed, six-armed, white Mañjuśrī at the same level as the Âdibuddha figure, and on the other side of the Maitreya statue. ${ }^{51}$ The iconographic situation of the standing Ādibuddha figure in the Village Stūpa is not dissimilar. The stūpa contains three other standing mural figures, those of Prajñāpāramitā, Avalokiteśvara and Tārā. These four figures, each of the same size, flank, in two pairs, two clay statues placed on the main axis of the stüpa, one at each end. There are eight further murals on the side walls (that also flank two clay statues), each of which is half the size of the standing figure murals. The Mañjuśrī Ādibuddha figure is prominent, therefore, but not especially so. It appears to be of equivalent status to the other three standing figures depicted as murals. It is not clear how to read the apparent lack of high status accorded to these two Mañjuśrí figures at Mangyu. It seems possible that they were not understood as depictions of the Ädibuddha-and this despite their textual context, and in spite of their iconographic context in

50 Study of these two rows of repainted figures might clarify whether they are part of the mandala or not. A combination of sculptures and murals is found elsewhere: for example, in the Translator's Temple at Nako subsidiary deities of the Vajradhātu-maṇala are murals while the five tathägatas are sculptures (Luczanits 2004, 79-80).

51 This intriguing figure, which as far as I am aware has not been identified, has six arms: the principal pair in his lap in dhyāna-mudrä; an upper pair with an arrow (proper right) and bow (left), and a lower pair holding a lily (right) and a lotus flower (left). The six faces, in two rows of three, have two central white faces. The remaining four have the colours of the directions. The correspondence of the number of heads with the Mañjuśrī-jñānasattva as described by our commentators is suggestive. Could this be a Mañjuśrī-jñānasattva variant, or even an Ādibuddha variant, perhaps from another Nāmasamgīti commentarial tradition? 
the Alchi Sumtsek and the Lalung Serkhang. Further work on the iconographic programmes at Mangyu might clarify their roles. ${ }^{52}$

\section{Addendum: The Relationship between Agrabodhi's *Sādhanaupayika and Vilāsavajra's Nāmamantrārthāvalokin̄̄}

Agrabodhi's description of Mañjuśrī-jñānasattva, using images of the moon, a sapphire and the sun ("He is luminous like the autumn moon, with the choicest sapphire as a [head] crest. He is encircled as if by the light of the rising sun."), is very close to that of Vilāsavajra, close enough for one to be borrowed from the other. What makes the comparison more striking, and the likelihood of borrowing more certain, is that the three descriptions are also allusions-more or less quotations - to three Nämasamgiti i verse quarters, which are taken in the same order by both authors, but which are not in the order of the Nämasamgititi.

The three pādas are śaraccandrāmsśusuprabhaḥ (NS 125b), indranīlāgrasaccīrah (NS 126a), and bālärkamaṇdalacchāyah (NS 125c). Vilāsavajra's NMAA (see above) has śaracchaśānikaprabham indranīlāgrasaccìram bālārkamaṇdalacchāyaprabhämandalam. The second description, except for the change in case ending, quotes $N S 126 \mathrm{a}$. Both authors' descriptions also immediately follow a statement that Mañjuśrī-jñānasattva is six-faced. If we compare Agrabodhi's descriptions with the Tibetan translation of the NMAA their closeness becomes particularly clear:

|| ston ka'izla ba ltar gsalzhing || indra nïla'igtsug phud can || nyi ma 'char ka'i'od'dras bskor ||

AGRABODHI

| ston ka'i zla ba'i mdog can | indra nïla mtshog gi gtsug phud [|] nyima 'char ka'i ltar'od kyi dkyil 'khor gyis bskor ba |

VILĀSAVAJRA. D 2533, 39r1

52 Rather than exploring in any depth the iconography surrounding the two Mangyu figures, my goal in this paragraph has been to focus on the apparent oddness of their location, on the assumption, that is, that they should be identified as representations of Mañjuśrī as the Ādibuddha. Rather more has been published on the Village Stūpa than the Two-armed Maitreya Chapel. On the latter, see Luczanits 2004, 167-170; van Ham 2011, 42-55. On the former, see Linrothe 1994 and 1999, 173-174; Luczanits ibid., 170-174; van Ham ibid., 138158. Luczanits usefully comments that the square Village Stūpa has a main axis. Linrothe's 1994 article unfortunately came to my attention too late for me to consult. 
Alone, this passage does not provide sufficient evidence to establish a direction of borrowing. Either could be an expansion or contraction of the other. Vilāsavajra is the more descriptively elaborate of the two. Agrabodhi's text is in a seven-syllable metrical form (which is the case for his descriptions of the Ādibuddha as well as Mañjuśrī-jñānasattva), suggesting that the original Sanskrit passage was likely in verse. Further comparison of Agrabodhi's and Vilāsavajra's texts is required.

\section{6}

\section{Conclusions}

In summary, the Nāmasaṃgìti-related texts of Vilāsavajra, Mañjuśrīmitra, and Agrabodhi indicate that the eight-armed Mañjuśrì[-like] figures at Alchi, Mangyu and Lalung be identified as the Ādibuddha. Such an identification explains why the Alchi figure occupies the most prominent location in the Sumtsek. It makes sense of the organization of the murals of the topmost storey, with the Ādibuddha representing the deeper nature of Vairocana to his (proper) right and Prajñāpāramitā to his left. It also makes sense of the vertical organization of the storeys of the back (and most important wall), with the Âdibuddha vertically above, and again representing the underlying nature of, both Śākyamuni (on the second storey) and Maitreya (the future Buddha, whose large clay figure faces the entrance to the Sumtsek on the first storey). However, only the five-headed Mangyu figures have the number of heads described by our authors. The Alchi mural figure has four, and the clay figure at Lalung just three (or possibly four). These variations, which may or may not reflect local adaptation, remain to be accounted for.

Differences between the three textual descriptions examined both allow and disallow the possibility of differing influences. Thus, for the two figures at Mangyu, the colouring of their five faces points to a tradition associated with Vilāsavajra as a source, and not Mañjuśrīmitra: Agrabodhi, who does not describe the colours, is neither ruled in nor out. Also, the small clay figure above the Ādibuddha in the Lalung Serkhang is likely to be Mañjuśrī-jñānasattva as depicted by Agrabodhi or Vilāsavajra rather than Mañjuśrimmitra. ${ }^{53}$ Further,

53 Both Vilāsavajra's NMAA and Agrabodhi's *Sādhanaupayika were translated into Tibetan in the early eleventh century by Smrtijñānakīrti, who was working in eastern Tibet. It may seem unlikely that their tradition of $N S$ interpretation could be the source for the Lalung Serkhang images. However, Luczanits $(\mathbf{2 0 0 4}, \mathbf{1 2 2})$ has argued that the sculptures in Cave 2 at nearby Dunkar reflect influence from north-east India (via Nepal and central Tibet), 
if the Mahāvairocana mural beneath the clay Ādibuddha in the Serkhang is part of the main mandala, then together the three figures represent the triadic and complex deity described in each of the three texts discussed, but here as inflected by those of Agrabodhi and Vilāsavajra. Additionally, the evidence suggests that the mandalas surrounding the Alchi and Lalung figures are related to the Vajradhātu-maṇala of the Tattvasamgraha rather than the Dharmadhātuvāgiśvara-maṇḍala. A remaining puzzle concerns the positioning of the two Mangyu figures: their respective iconographic contexts raise questions about whether they were intended as, or perceived to be, depictions of Mañjuśrī as the Ādibuddha.

In wider perspective, the mid-eighth to early-ninth century Indian textual portrayal of Mañjuśrī as the Ādibuddha, and as the Jñānasattva, by Mañjuśrīmitra, Agrabodhi, and Vilāsavajra (to place them in their likely chronological order) reveals what is hard not to read as a concerted effort during this period to promote Mañjuśrī as the key tantric deity. While the effort ultimately failed, as a result of competing claims for the role of Ādibuddha (for example by supporters of Vajrasattva, Vajradhara, and Samantabhadra) and by the increasing dominance of the newer yoginitantra traditions, it is nonetheless significant that this yogatantra-based vision of Mañjuśrī as the Ādibuddha still had currency some two to four hundred years later in the artistic portrayals found in early Western Himalayan Buddhist art.

The findings of the present investigation also give clear support to the suggestion, made by both Linrothe and Luczanits, ${ }^{54}$ of the importance of the Nāmasamgīti and its associated literature in understanding the role of Mañjuśrī in Western Himalayan Buddhist art.

and although he sees Lalung's artistic origins as being in north-west India, perhaps some textual/iconographic influence may have come from the east. If the Lalung Serkhang dates from the second half of the twelfth century (see above, note 4) there would be ample time for transmission of a Vilāsavajra/Agrabodhi based iconographical tradition. In the case of Mañjuśrīmitra's text there is no equivalent issue of geographical transmission. Rinchen Zangpo played a major role in the development of Buddhism in the Western Himalayas, becoming associated with many of its temples and monasteries, and although he did not translate the $\bar{A} k \bar{a}$ śavimala, he did translate both the $N S$ and Mañjuśrīmitra's $N S$ commentary (see note 14 above).

54 See Linrothe 1996, 272 and Luczanits 2004, 212-214. 


\section{Abbreviations}

D Catalogue of the Derge edition of the Kanjur and Tenjur published by Tōhoku Imperial University. See Ui Hakuju et al. 1934.

NMAA Nāmamantrārthāvalokin̄̄ of Vilāsavajra

NGMPP Nepal-German Manuscript Preservation Project

Ns Nāmasamgìti

WHAV Western Himalaya Archive Vienna

\section{Acknowledgements}

As my doctoral supervisor, Professor Sanderson gave of his time, enthusiasm, deep knowledge and friendship with extraordinary generosity. I owe him a very large debt of gratitude. For help on the present article thanks are due to Verena Widorn, director of the Western Himalaya Archive Vienna (WHAV) at the University of Vienna, for providing invaluable photographs; to Cécile Ducher for her overview of the Tibetan translations; and to Jaroslav Poncar, Christian Luczanits and Christiane Papa-Kalantari for photograph permissions.

\section{References}

\section{Primary Sources}

\section{$\bar{A} k a ̄ s ́ a v i m a l a$ of Mañjuśrīmitra}

Nāmasamgītimaṇḍlavidhyākāśavimalanāma; Mtshan yang dag par brjod pa'i dkyil 'khor cho ga nam mkha' dri med ces bya ba, trans. Suvajra pa and Chos kyi shes ra. Sde-ge Bstan-gyur, Rgyud-'grel, vol. ngu, ff. 1v1-13v6 (D 2543).

\section{Tattvasamgraha}

Yamada Isshi, ed. Sarvatathāgata-tattvasamgrahanāma-mahāyānasūtra: a CriticalEdition Based on a Sanskritmanuscript and Chinese and Tibetan Translations. Śatapițaka Series, no. 262. New Delhi: Sharada Rani, 1981.

\section{Nāmamantrārthāvalokin̄̄ (NMAA) of Vilāsavajra}

See Tribe 2016.

Manuscript belonging to the University of Cambridge (Bendall, 1883: Add. 1708). Palmleaf, Nevārī script, 115 folios (c. 145 o CE). (siglum A)

Manuscript belonging to P.R. Vajrācārya, Kathmandu (NG M PP reel no. E 36o/16). Paper, Nevārī script (first 13 folios lost), undated. (siglum B) 
Manuscript belonging to Dharmavajrācārya, Kathmandu (NGMPP reel no. E 1369/3). Paper, Devanāgarī script, 194 folios, undated. (siglum D)

Āryanāmasamgītițīkā Nāmamantrārthāvalokini; 'Phags pa mtshan yang dag par brjod pa'i rgya cher 'grel pa mtshan gsang sngags kyi don du rnam par lta ba, trans. Smṛtijñānakīrti. Sde-ge Bstan-gyur, Rgyud-'grel, vol. khu, ff. 27v1-115v3 (D 2533).

\section{Nāmasamgīti (Ns)}

See Davidson 1981.

\section{Nișpannayogāvalī (NYĀ) of Abhayākaragupta}

Benoytosh Bhattacharyya, ed. Niṣpannayogāvalī of Mahāpaṇdita Abhayākaragupta. Gaekwad's Oriental Series, no. 109. Baroda: Oriental Institute, 1949.

\section{*Sādhanaupayika of Agrabodhi}

Āryamañjuśrīnāmasamgītinopika; 'Phags pa 'jam dpal gyi mtshan yang dag par brjod pa'i sgrub pa'i thabs, trans. Smṛtijñânakîrti. Sde-ge Bstan-gyur, Rgyud-'grel, vol. ngu, ff. 59r4-70v2 (D 2579).

\section{Secondary Sources}

Bendall, Cecil. 1883. Catalogue of the Buddhist Sanskrit Manuscripts in the University Library, Cambridge. Cambridge: Cambridge University Press.

Davidson, Ronald M. 1981. "The Litany of Names of Mañjuśrī." In Tantric and Taoist Studies in Honour of Professor R.A. Stein, vol. 1, edited by Michel Strickmann, 1-69. Mélanges chinois et bouddhiques 20. Brussels: Institut belge des hautes études chinoises.

Edgerton, Franklin. 1953. Buddhist Hybrid Sanskrit Grammar and Dictionary. 2 vols. New Haven: Yale University Press.

Goepper, Roger, and Jaroslav Poncar. 1996. Alchi: Ladakh's Hidden Buddhist Sanctuary. The Sumtsek. Chicago: Serindia Publications.

Levy, Rachel Q., and Luke A. Fidler. 2014. "The Date of the Alchi Sumtsek Murals: 11th or 13th Century?" International Association for Ladakh Studies 31: 37-38.

Linrothe, Robert. 1994. "The Murals of Mangyu. A Distillation of Mature Esoteric Buddhist Iconography." Orientations 25 (11): 92-102.

Linrothe, Robert. 1996. "Mapping the Iconographic Programme of the Sumstek." In Alchi: Ladakh's Hidden Buddhist Sanctuary. The Sumtsek, by Roger Goepper and Jaroslav Poncar, 269-272. Chicago: Serindia Publications.

Linrothe, Robert. 1999. Ruthless Compassion. Wrathful Deities in Early Indo-Tibetan Esoteric Buddhist Art. London: Serindia.

Linrothe, Robert. 2011. "Dating the Mangyu Style." In Heavenly Himalayas: the Murals of Mangyu and Other Discoveries in Ladakh, by Peter van Ham, 158-161. Munich and New York: Prestel. 
Luczanits, Christian. 2004. Buddhist Sculpture in Clay: Early Western Himalayan Art, Late 1oth to Early 13th Centuries. Chicago: Serindia.

Pal, Pratapaditya, and Lionel Fournier. 1988. Marvels of Buddhist Art:Alchi-Ladakh. New York and Paris: Ravi Kumar.

Ricca, Franco, and Erberto Lo Bue. 1993. The Great Stupa of Gyantse: A Complete Tibetan Pantheon of the Fifteenth Century. London: Serindia.

Snellgrove, David L., and Tadeusz Skorupski. 1977, 1980. The Cultural Heritage of Ladakh. 2 vols. Warminster: Aris and Phillips.

Tanaka Kimiaki. 2018. An Illustrated History of the Maṇdala: From its Genesis to the Kälacakratantra. Somerville, MA: Wisdom Publications.

Tribe, Anthony. 1997. "Mañjuśrī and 'The Chanting of Names' (Nāmasaṃīti): Wisdom and its Embodiment in an Indian Mahāyāna Buddhist Text." In Indian Insights: Buddhism, Brahmanism and Bhakti. Papers from the Annual Spalding Symposium on Indian Religions, edited by Peter Connolly and Susan Hamilton, 109-136. London: Luzac Oriental.

Tribe, Anthony. 2015. "Mañjuśrīnāmasamgīti." In Brill's Encylopedia of Buddhism, vol. ı: Literature and Languages, edited by Jonathan Silk, Oskar von Hinüber, and Vincent Eltschinger, 353-359. Leiden: Brill.

Tribe, Anthony. 2016. Tantric Buddhist Practice in India: Vilāsavajra's Commentary on the Mañjuśrì-nāmasamgīti. A Critical Edition and Annotated Translation of Chapters 1-5 with Introductions. London and New York: Routledge.

Tucci, Giuseppe. 1988. The Temples of Western Tibet and their Artistic Symbolism. IndoTibetica III.1: The Monasteries of Spiti and Kunavar. English translation, edited by Lokesh Chandra. Śatapițaka Series, no. 349, New Delhi: Aditya Prakashan. Originally published 1935. I templi del Tibet occidentale e il loro simbolismo artistico. Parte 1. Spiti e Kunavar. Roma: Reale Accademia d'Italia.

Ui Hakuju, Suzuki Munetada, Kanakura Yensho, and Tada Tokan, eds. 1934. A Complete Catalogue of the Tibetan Buddhist Canons (Bkah-hgyur and Bstan-hgyur). Sendai: Tōhoku Imperial University.

van Ham, Peter. 2011. Heavenly Himalayas: the Murals of Mangyu and Other Discoveries in Ladakh. Munich and New York: Prestel.

van Ham, Peter. 2019. Alchi: Treasure of the Himalayas. Munich: Hirmer.

van Schaik, Sam. 20o9. "A Tibetan Book of Spells." Blog entry, https://earlytibet.com/ 2009/o2/19/a-tibetan-book-of-spells/ (accessed May 15th 2020). 